
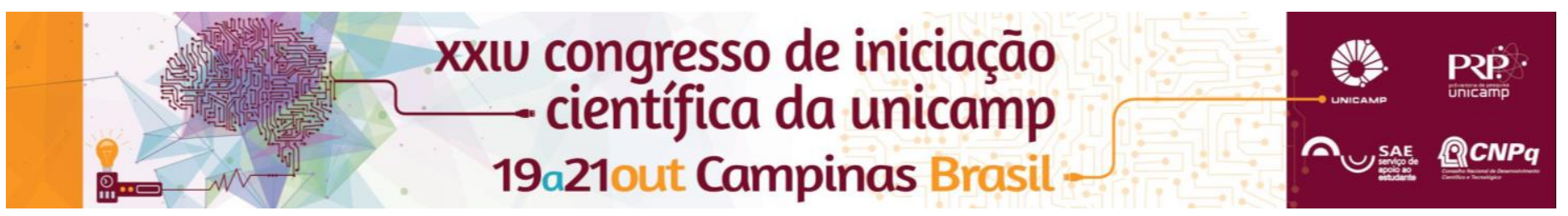

\title{
O corpo e a dança: entre fotografias e desenhos
}

\section{Rodrigo Henriques de Faria*}

\section{Resumo}

A pesquisa consiste em estabelecer uma simbiose entre a dança e o desenho, a partir de duas situações distintas: a representação do movimento a partir do gesto, em que a mão e o olho acompanham o movimento da bailarina, criando desenhos gestuais com traço solto e a representação a partir de fotografias de movimentos.

\section{Palavras-chave}

Desenho, Fotografia, Dança.

\section{Introdução}

Durante sete meses foram acompanhados os ensaios da turma 2012 do curso de dança. Desses encontros surgiram desenhos gestuais com a bailarina ao vivo, fotografias de apresentações e bastidores, além de pinturas a partir dessas imagens. A obra de Edgard Degas é a referência principal da pesquisa, haja visto que 0 artista foi um dos primeiros a realizar pinturas a partir da fotografia, no final do século XIX. O objetivo geral é representar o movimento a partir de diferentes abordagens e técnicas, verificando o potencial e as problemáticas de cada uma.

\section{Resultados e Discussão}

A seguir apresento as imagens referentes à metodologia e aos resultados. Figuras 1 e 2 referem-se as sessões de desenho gestual com modelo vivo. As figuras 3 e 4 são registros fotográficos dos ensaios da turma 2012 de dança do Instituto de Artes da Unicamp. As figuras 5, 6 e 7 são referentes aos exercícios de desenho a partir do acervo fotográfico coletado durante o acompanhamento do trabalho de conclusão de curso em dança.

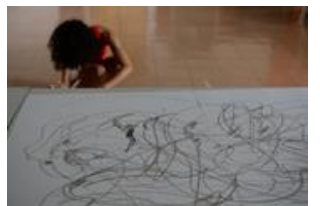

Figura 1. Sessão de desenho com modelo

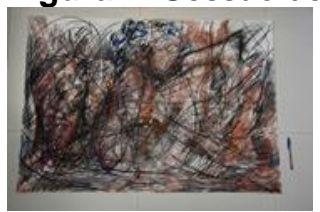

Figura 2 Desenho do autor

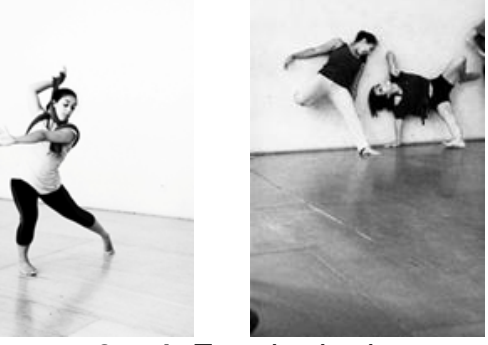

Figuras 3 e 4. Ensaio de dança
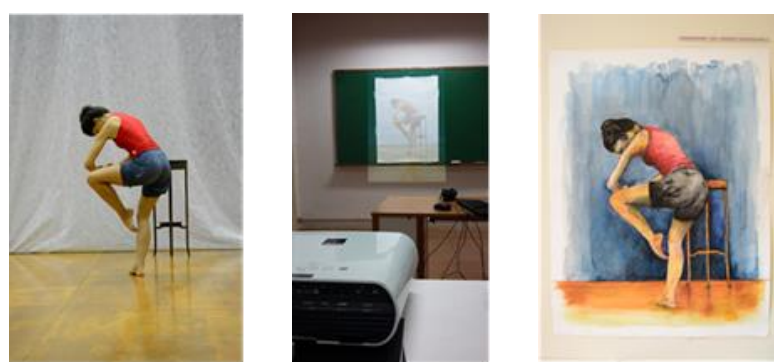

Figura 5. Bailarina Flávia Pinheiro

Figura 6. Projeção de imagem sob papel

Figura 7. Desenho a partir de fotografia projetada

\section{Conclusões}

Os diferentes meios de se representar o corpo e o movimento enfatizam um determinado aspecto da realidade, pois nenhuma representação é capaz de substituir a experiência de estar diante das bailarinas. Desse modo, tanto a foto quanto o desenho são um vestígio desse encontro entre o observador e a bailarina, cuja representação é inevitavelmente impregnada de códigos e referenciais pertencentes à cultura e ao período histórico em que vivemos.

\section{Agradecimentos}

Agradeço a professora Luise Weiss pela confiança no meu trabalho, pela paciência e pelo entusiasmo com que desenvolve a sua orientação. Ao Pibic/Cnpq pelo financiamento do projeto, que possibilitou o trabalho com materiais gráficos de alto desempenho e a revelação das fotografias. Faço um agradecimento especial às bailarinas da turma 2012 do curso de dança (grupo Kyma) e principalmente à Flávia Pinheiro, bailarina modelo dos desenhos gestuais, pela sensibilidade e comprometimento

\footnotetext{
1 SCHARF, Aaron. Arte y fotografia. Madrid: Alianza, 1994.

2 LORD, James. Um retrato de Giacometti. São Paulo-SP: Iluminuras, 1998
} 